Karatay, H., Dolunay, S.K. ve Savaş, Ö. (2014). Türkçe öğretmenlerinin etkin dinleme ve dönüt durumları. Ana Dili Eğitimi Dergisi, 2(4), 85-106.

Ana Dili Eğitimi Dergisi
Journal of Mother Tongue Education
ADED - JOMTE
www.anadiliegitimi.com

\title{
Türkçe Öğretmenlerinin Etkin Dinleme ve Dönüt Durumları ${ }^{*}$
}

\author{
Halit Karatay $^{* *}$ \\ Salih Kürşad Dolunay ${ }^{* * * * *}$ \\ Ömer Savaş ${ }^{* * *}$
}

\begin{abstract}
Özet
Etkin dinleme, dinleyicinin konuşan kişiyi tam olarak anlamayı hedeflediği ve bunu gösteren geri iletimlerde bulunduğu dinleme yöntemidir. Etkin dinleme becerisinin öğrencilere kazandırılmasında çok büyük rolü olan Türkçe öğretmenleri, bu beceriden yararlanarak onlara örnek olmak durumundadır. Bu araştırmada, Türkçe öğretmenlerinin, etkin dinlemenin göstergesi olan sözlü dönüt tekniklerinden ne kadar ve ne oranda yararlandığı belirlenmiştir. Araştırmada katııımlı gözlem ve görüşme teknikleri kullanılmıştır. Araştırmanın çalışma grubu, amaçlı örnekleme yöntemi ile belirlenmiştir. Çalışma grubu, Bolu il merkezindeki farklı sosyoekonomik çevrelerde bulunan 6 ortaokulda çalışan 5 bay ve 5 bayan Türkçe öğretmenidir. Etkin dinleme tekniklerini uygulama durumlarını belirlemek için öğretmenler farklı zamanlarda 40 ders saati gözlemlenmiştir. Öğretmenlerin kullandıkları tekniklerin içerik analizi yapılarak bunlar kendi içinde sınıflandııımış, kullanım sayıları ve oranları belirlenmiştir. Buna göre öğretmenlerin yansıtma ve soru sorma tekniklerini kullandıkları, duyguların anlaşıldığını gösterme tekniğini hiç kullanmadıkları görülmüştür. Ayrıca sınıfta kullanılan dönütlerin çoğunun etkin dinleme tekniği niteliği taşımadığı ve etkin dinleme tekniklerinin kullanımındaki dağılımın oldukça çarpık olduğu belirlenmiştir. Öğretmenlerle yüz yüze yapılan görüşmeler ise, çoğunun etkin dinleme teknikleri hakkında yeterli düzeyde bilgi sahibi olmadığını göstermiştir.
\end{abstract}

Anahtar kelimeler: Türkçe eğitimi, dinleme eğitimi, etkin dinleme, dönüt, soru sorma.

\section{Active Listening Feedback Usage of Turkish Language Teachers}

\begin{abstract}
Active listening is a listening skill in which listener aims to fully understand and displays feedback that shows this intention. Turkish language teachers who have an important role teaching that skill to students must give the lead by utilizing it. In this study, quantities and ratios of active listening techniques' which teachers utilized are identified using participant observation and interview. 10 Turkish language teachers work in Bolu had been sampled according to their genders, ages and socio-economic status of schools they work. Sampled 5 male and 5 female teachers work in 6 secondary schools. To capture verbal feedbacks given to students, teachers were observed for 4 hours each. Then active listening techniques used by teachers, were content analyzed. Categories, quantities and ratios of these were identified. Analysis indicate that; teachers use reflecting and asking question techniques, but they don't use presenting speaker's feelings. Most of feedbacks are not active listening techniques and the distribution of active
\end{abstract}

\footnotetext{
* Bu araştırma, Abant İzzet Baysal Üniversitesi Bilimsel Araştırma Projeleri tarafından desteklenmiştir. Proje no: 2013.02.05.617.

** Doç. Dr., Abant İzzet Baysal Üniversitesi Eğitim Fakültesi Türkçe Eğitimi Bölümü, Bolu, karatay_h@ibu.edu.tr

*** Yrd. Doç. Dr., Abant İzzet Baysal Üniversitesi Eğitim Fakültesi Türkçe Eğitimi Bölümü, Bolu, dolunay_k@ibu.edu.tr

**** Arş. Gör., Abant İzzet Baysal Üniversitesi Eğitim Fakültesi Türkçe Eğitimi Bölümü, Bolu, omersavas@ibu.edu.tr
} 
listening techniques' is uneven. Besides face to face interviews show that most of the teachers are not well informed about active listening.

Keywords: Turkish language education, listening education, active listening, feedback, asking question.

\section{Giriş}

Insanoğlu, yaradılışı gereği öğrenme, düşünme ve bildiklerini aktarma ihtiyacı hisseder. Bunu yaparken de birtakım duyu ve becerilerden yararlanır. İşitme duyusu ve dinleme becerisi, bunlar arasında en ilkel olan öğrenme yoludur. Konuşma yoluyla gönderilen iletinin anlaşılması için ilk önce işitilebilmesi-duyumsanabilmesi, yani duyma eşiğini geçmesi, bunun ardından iletinin tam ve doğru anlamlandırılabilmesi için de dikkat-odaklanmanın gerçekleşmesi, yani dinlenilmesi gerekir.

Dil gelişimi, doğal olarak okul öncesinden itibaren ailede ve sosyal çevrede dinleme ve konuşma becerilerinin edinimi ile başlar. Bu beceriler okul öncesinden itibaren sürekli gelişim gösterse de okullarda planlı eğitim faaliyetleri ile bunların doğru ve etkin kullanımı sağlanmaya çalışılır. Verilen dil eğitiminin niteliğine bağı olarak dil becerilerinin gelişimi arasında farklar oluşur. Bu farkların kapanması ve etkili dinleme becerisinin kazandırılması yolunda eğitim sisteminin paydaşlarına büyük görevler düşmektedir (Doğan, 2011: 9 ve 18).

Illköğretim Türkçe Dersi Öğretim Programlarında "dinleme" bir öğrenme alanı olarak yer alır (MEB, 2006; MEB, 2009). Illetişim becerisinin önemli bir ögesi olan dinlemenin geliştirilmesi için hem ilkokul hem de ortaokul programında yer alan teknik ve yöntemler arasında katılımlı (etkin) dinlemeye yer verilmiştir.

\section{Etkin Dinleme}

Etkin dinleme, alan yazında dinleme yöntemlerinden biri olarak aktif dinleme (Gordon, 2013; Çiftçi, 2007) ve katılımlı dinleme (Doğan, 2011) adlarıyla karşılanmaktadır. Sözlü iletişim kurmanın temeli olarak kabul edilen bu dinleme yöntemini önemli kılan, "günlük yaşantımızın her aşamasında geçerliliğini sürdüren bir dinleme türü" olması (Yalçın, 2006: 132), insanlar arasında güven ve anlaşmayı sağlamasıdır (Salem, 2003).

"Etkin dinleme, Gordon tarafından etkili veli-çocuk ilişkisi için zorunlu olan birtakım sözlü ve sözsüz beceriler olarak terimleştirilmiş olsa da, kökü daha eski araştırmalardadır. Etkin veya empatik dinleme, insancıl psikolojisinin temel taşı olarak Rogers'a dayandırılabilir" (Orlov, 1992). Etkin dinleme; dinleyicinin, empati, koşulsuz saygı, ve samimiyet (Rogers, 1955; Akt.: Mishima, Kubota ve Nagata, 2000) duygularının eseri olarak, konuşanı, onun duygu ve düşüncelerini tam olarak anlamayı hedefleyen bir dikkat ve ilgiyle, göz teması kurarak, sözünü kesmeden, fikir ve duygularının anlaşlıp anlaşılmadığını gösteren, yargılayıcı olmayan sözlü ve sözsüz geri iletimde bulunarak dinlemesi yöntemidir (Gordon, 2004; Weger, Castle ve Emmett, 2010; Bodie, 2011; Hanna, 2011; Mishima, Kubota ve Nagata, 2000; Cihangir Çankaya, 2011; Hutchby, 2005). 
Etkin dinleme, bütün insanları ilgilendiren temel bir iletişim becerisidir. Bunun için etkin dinleme becerisi programlı eğitim yoluyla öğrencilere kazandırılmalıdır. Çünkü etkin dinleme, kişiye gündelik hayatta lazım olan bir beceri olmasının yanında eğitim kurumlarında, sınıf içi ve dışı iletişim durumlarında kullanıldığında insanlar arasında anlaşmayı ve olumlu ilişkiyi destekleyen özelliklere sahiptir (Gordon, 2013). Nitekim Gordon'a (2004: 72) göre "Etkin dinleme, öğrenmeyi kolaylaştırmada, sorgulamayı yüreklendirmede, öğrencilerin düşünme, tartışma, soru sorma ve araştırmada kendilerini özgür hissedecekleri ortamı yaratmada güçlü bir araçtır." Gordon (2004: 13), ayrıca bu becerinin önemini "Etkin dinleme becerisi her çocuk için harikalar yaratır. Çünkü her çocuk dinlenilmek, anlaşılmak ve kabul edilmek ister." diye ifade etmiştir. Öğretmenlerin bu beceriyi geliştirebilmesi için her şeyden önce öğrencilerine iyi birer model olmaları gerekir.

\section{Etkin Dinlemede Dönüt Teknikleri}

İletişimin önemli ögelerinden biri olan dönüt, kaynaklarda geri-iletim (Cüceloğlu, 2013) olarak da geçmektedir. "Kaynak birimin gönderdiği mesaja karşılık, hedef birimin verdiği 'cevap mesaj'a, geriiletim adı verilir" (Cüceloğlu, 2013: 71). Dinleme bağlamında düşünülecek olursa, dinleyicinin konuşucuya verdiği tepkiye "dönüt" denir.

Sözlü iletişimde konuşana karşılık olarak gerçekleştirilen "dönüt", dinleyicinin dinleme gayreti içerisinde olup olmadığına dair ipucu özelliği taşır. Çünkü samimiyeti belirlenemese de dönüt, iletinin dinleyiciye ulaşıp ulaşmadığı konusunda konuşan için somut ve gözlemlenebilir bir veridir. Bunun için dönüt, kişiler arası iletişimde iletinin amacına ulaşıp ulaşmadığını, dinlemenin gerçekleşip gerçekleşmediğini gösterir.

Etkin dinlemenin üç temel bileşeni vardır. Bunlar: "algılama, zihinsel süreç ve karşılık verme". Algılama ve zihinsel süreç, karşılık vermeyi etkiler fakat karşılık verme diğerlerine göre daha somuttur (Comer ve Drollinger, 1999: 16-17). Bunun için etkin dinleme teknikleri, genel olarak "karşılık verme"nin üzerine kurulur. Çünkü etkin dinlemenin amaçlarından biri konuşucuya dinlenildiğini hissettirip onu rahatlatmak ve cesaretlendirmektir (Gordon, 2013: 100).

Etkin dinleme teknikleri adı verilen teknikler, aslında birer dönüt tekniğidir. Bunlar belirli biçimlerde geri-iletimde bulunmak yoluyla iletişimin seyrini olumlu yönde etkiler. Bu teknikler kullanılarak karşılık verilen konuşucu, dinlenildiğini anlar, bu da onu cesaretlendirir.

Alan yazın incelendiğinde, ortak yönleri fazla olmakla birlikte kaynaklarda farklı biçimlerde yer alan etkin dinleme teknikleri arasından aşağıdaki üçü temel teknik olarak kabul edilebilir (AntaiOtong, 1999: 24; Andersen, 2008: 85-85; DeVito, 1995, akt. Cihangir Çankaya, 2011: 47; Gordon, 2013: 111-112; Comer ve Drollinger, 1999: 17; Hoppe, 2006: 15-18).

1. Yansitma

2. Duyguların anlaşıldığını gösterme

3. Soru sorma 
Bu üç teknik, DeVito'nun (1995, akt. Cihangir Çankaya, 2011: 47-49) sınıflandırmasının daha genel ve kapsayıcı olduğu düşünüldüğünden araştırmada esas alınmıştır.

\section{Yansıtma}

Yansıtma, konuşucunun ifadesinin içerik olarak anlaşıldığını göstermek amacıyla dönüt verme şeklinde gerçekleşir. Bu, onay ya da ret içermeyen ifadelerle yapılır (Hoppe, 2006: 15). Bu amaçla, konuşanın ifade ettiklerini dinleyici, "aynen tekrar etme, başka türlü ifade etme, anahtar kelimeyi söyleme, özetleme veya yorumlama" yoluyla yansıtır (Hoppe, 2006: 12-18; Mackay, 1997: 26; Birden, 2001: 63; Andersen, 2008: 85-86; Lawrence, 1997: 31; Cheon ve Grant, 2009: 25; Matheson, Moon ve Winiecki, 2000: 27-30; Karaköse, 2005: 17). Aynen tekrar etme; konuşucunun ifadelerini değiştirmeden söyleyerek yansıtma tekniğidir. Bu teknik, muhataba dinlenilip dinlenilmediği konusunda ipucu sağlar (Karaköse, 2005: 17). Başka türlü ifade etme; konuşucunun söylediklerini anlam olarak değiştirmeden farklı bir şekilde ifade ederek yansıtma tekniğidir (Lawrence, 1997: 31). Bu tekniğin, dinlemenin gerçekleştiğini gösterme yeterliliği, aynen tekrar etmeye göre daha fazladır. Çünkü burada dil yapısının dönüştürülmesi söz konusudur. Bir anlamı farklı bir dil yapısına büründürmek için de kişinin anlama sürecinden geçmiş olması gerekir. Anahtar kelimeyi söyleme; konuşucunun söylediklerini özet gibi cümlelerden oluşan bir yapıda değil de bir kelime veya kelime grubuyla yansıtması şeklinde uygulanmaktadır (Mackay, 1997: 26). Bu teknikte önemli olan, söylenen kelime veya kelime grubunun anahtar kelime niteliği taşıması, yani ifade edilenler hakkında fikir vermesidir. Özetleme; yazılı anlatım terimi olarak kullanılan “özetleme”nin sözlü anlatıma uyarlanmış biçimidir. Konuşucunun söylediklerindeki ayrıntıları eleyerek, asıl ifade edilmek isteneni yansıtan ve bir cümleden veya cümlelerden oluşan dönüt, özetleme kapsamında değerlendirilmektedir (Matheson, Moon ve Winiecki, 2000: 30). Bu yönüyle anahtar kelimeyi söylemeye benzer fakat bu dönüt biçimi cümle veya cümleler şeklinde kurulur. Yorumlama ise konuşucunun ifade ettiği konudan sapmadan söylenenlere anlamsal olarak bir şeyler katmak suretiyle verilen dönüttür (Hoppe, 2006: 18). Burada yeni bilgiler vermek, düzeltme yapmak, söyleneni reddetmek değil, verilen bilgiyi başka bir açıdan ele almak söz konusudur. Bu teknik, söylenenlerin anlamsal içeriğinde değişikliğe sebep olması bakımından diğer yansıtma tekniklerinden farklıdır. Bu yüzden bu tekniğin ne şekilde kullanıldığı önemlidir. Çünkü etkin dinlemenin ilkelerine aykırı yapılan yorumlama, bir etkin dinleme tekniği değildir. Bu gibi durumlarda iletişim engeli ortaya çıkmaktadır.

Gordon'un (2013: 101-111) belirlediği 12 iletişim engeli, hangi içeriğe sahip dönütlerin iletişimi olumsuz yönde etkilediğini ortaya koymaktadır. Söz gelimi bu listeye göre bir öğretmen kullandığı ifadeyle öğrenciyi yargılıyorsa, bu dönüt "yargılamak, eleştirmek, katılmamak, suçlamak" iletişim engeline dâhildir. Sınıf ortamında verilen dönütlerin nasıl olmaması gerektiğini gösteren 12 iletişim engeli şunlardır (Gordon, 2013: 101-111):

1. Emir vermek, yönetmek, yönlendirmek 
2. Uyarmak, tehdit etmek

3. Ahlak dersi vermek, öğüt vermek, yapması ve yapmaması gerekenleri söylemek

4. Nasihat etmek, çözüm veya öneriler sunmak

5. Öğretmek, ders vermek, mantık kullanmak, delil vermek

6. Yargılamak, eleştirmek, katılmamak, suçlamak

7. İsim takmak, alay etmek

8. Yorumlamak, analiz etmek, teşhis etmek

9. Övmek, katılmak, olumlu değerlendirmeler yapmak

10. Güvence vermek, yakınlık göstermek, teselli etmek, desteklemek

11. Soru sormak, araştırmak, sorgulamak, çapraz sorgulamak

12. Sözünden dönmek, dikkat dağıtmak, alaycı olmak, şakacı olmak, konuyu saptırmak

8. maddede yer alan "yorumlama"nın, etkin dinleme tekniği olan "yorumlama"dan farklı olduğu bilinmelidir. Çünkü burada yer alan yorumlama, öğrencinin sözlerini, şahsı ile ilgili olarak analiz etme anlamına gelmektedir. Bu madde için verilen örnekteki öğretmenin şu ifadesine bakarak söz konusu fark anlaşılabilir: "Bunu sadece dikkat çekmek için yapıyorsun." (Gordon, 2013: 106) vb.

\section{Duyguların Anlaşıldığını Gösterme}

Bu teknik, konuşucunun ifadelerinin ve beden dilinin içerisinde gizli ya da açıkça var olan duygunun anlaşıldığını ortaya koyar. Bu tekniği kullanan dinleyici, bazı durumlarda, yüzeysel anlamı aşıp derin anlama ulaştığını, konuşucunun gerçek amacını fark ettiğini ve duygularını anladığını belirtmiş olur. Böylece konuşucu gerçek anlamda dinlenildiğini anlar (DeVito, 1995, akt. Cihangir Çankaya, 2011: 47-49). Ayrıca birçok durumda bu teknik, duygudaşlık kurmanın yerine geçer (Hanna, 2011: 7). Bu tekniğe şöyle bir örnek verilebilir:

Öğrenci: Keşke dünyada hayvanlar yerine Pokemonlar olsaydı.

Öğretmen: Pokemonları çok seviyor olmalısın.

$\mathrm{Bu}$ tekniğin sınıf ortamında kullanıımasının bazı koşullarda sakıncalı olma ihtimali akla gelebilir. Alan yazında bu konuda herhangi bir bilgiye ulaşılamamıştır. Ancak bu tür bir dönüt, etkin dinleme ilkelerine göre değerlendirildiğinde ortaya çıkan sonuç, söz konusu risk hakkında aydınlatıcı olacaktır. Etkin dinleme ilkeleri veya etkin dinleyici olabilmenin koşulları şu şekilde sıralanmıştır (Karaköse, 2005: 15):

1. Illetişim için istekli olun.

2. Göz teması kurun.

3. İlgi gösterin (başla onay, mimikler).

4. Dikkat dağıtan davranışlardan kaçının (saate bakmak, kalemle oynamak vs.).

5. Olayın bütününe dikkat edin (duygular, beden dili, içerik).

6. Soru sorun. 
7. Duyduklarınızı kendi kelimelerinizle ifade edin.

8. Söz kesmeden, tahminde bulunmadan dinleyin.

9. Empatik olun.

10. Söylenenleri toparlayın.

11. Çok ve gereksiz konuşmayın.

12. Önyargılarınızı engellemeye çalışın.

13. Konuşma ve dinleme arasında dengeli geçişler yapın.

14. Doğal olun.

Dinlerken bu kurallara uyulduğu ve daha önce bahsedilen 12 iletişim engelinden kaçınıldığı takdirde duyguların anlaşıldığı karşı taraftakine dönüt şeklinde hissettirilebilir.

\section{Soru Sorma}

Soru sorma tekniği kullanılarak iletinin daha iyi anlaşııması sağlanabileceği gibi konuşucunun konuyu açması, daha önce söylemediklerini söylemesi de sağlanabilir (Lawrence, 1997: 32). Ayrıca soru sorma, bazen bir şey öğrenme maksadı taşımaz, konuşucuyu belli bir düşünceye yönlendirme amacıyla da kullanılır (Hoppe, 2006: 17). Her ne amaçla kullanılırsa kullanıısın, konuşucuya yöneltilen sorular, dinlemenin gerçekleştiğini gösteriyor ve konuşucuyu cesaretlendiriyorsa iletişim açısından olumludur. Bu özelliği taşıyan sorular etkin dinleme tekniği niteliği taşır.

Etkin dinlemede üç soru sorma tekniği vardır. Bunlar, "açık uçlu soru, açıklatıcı soru ve sondaj sorusu sorma"dır. Açık uçlu sorular, konuşucuyu düşüncelerini ifade etmesi yönünde cesaretlendirir. Bunlar, doğru cevabı buldurma amacı taşımaz; "evet, hayır" ile cevaplandırılamaz. Ayrıca dinleyiciyi düşüncesini savunmaya da itmez. Bu tip sorulara "Bu konudaki düşüncelerin neler?” ifadesi örnek verilebilir. Açıklatııı sorular alan yazında "clarifying questions" olarak geçmektedir. Bu soru tipinde amaç, anlamayı artırmak, anlam karmaşasını gidermektir. 5N1K soruları bu kategoride yer alır. Bunlara örnek olarak "Anlamadığım bir şey oldu: Olay ne zaman geçiyordu?" soru yapısı verilebilir. Soru sorma tekniğinin diğer bir türevi de sondaj sorusudur. Sondaj sorusu; "dinleyene doğrudan öneride bulunmak yerine, onu düşünmeye ve akıllıca karşılık vermeye" yöneltir. Bu yolla yeni düşünceler ortaya çıkarılırken bu düşüncelerin karşı tarafın kendisine ait olduğunu görmesi sağlanır. Çünkü söz konusu düşünceler, konuşucunun kendi düşünme süreçleri sonucunda ortaya çıkmış olur. Bu tip soruya örnek olarak şu ifade verilebilir: "Tonya'nın işlerini yetiştirememesinde rol oynamış olabilecek liderlik yaklaşımı özelliklerin neler olabilir?" (Hoppe, 2006: 16 ve 17). Soru sorma tekniği diğer tekniklere göre etkin dinleme, özellikle eleştirel düşünmeyi daha somut biçimde ölçer, konuşmada hem dinleyen hem de konuşan daha üst düzeyde iletişim içindedir.

\section{Araştırmanın Amacı}

Sınıf içindeki öğretmen-öğrenci ve öğrenci-öğrenci arasında gerçekleşen iletişim ortamı, öğrencilerin sınıf dışında birbirleriyle iletişim kurmalarına da örnek olur. Bu açıdan bakıldığında etkin 
dinleme, bireylerin okul yaşamlarından toplumsal yaşamlarına açılan penceredir, doğru iletişim biçimini belirleyen ve özellikle okulda edinilmesi gereken önemli bir beceridir. Bu becerinin edinilmesinde öğretmenlerin sınıf içi iletişim hakkındaki teorik bilgisi kadar derslerde yaptıkları uygulamaların niteliği ve farkındalığı önemlidir. Alan yazında öğretmenlerin sınıf içi iletişimde etkin dinleme ve dönüt durumlarını inceleyen bir çalışmanın olmayışı, bu alanın ihmal edildiğini veya gözden kaçırıldığını gösterir. Çocuklarda etkin dinleme becerisinin yeteri kadar gelişememesinde aile çevrelerinde anne ve babalarının, yakın çevrelerinde yetişkinlerin ve sınıfta ise öğretmenlerinin iyi bir model olmaması rol oynamaktadır. Bu durumu sınıf içinde gözlemlemek için araştırmanın problem cümlesi şu şekilde belirlenmiştir.

\section{Araştırmanın Problem Cümlesi}

Türkçe öğretmenleri, sınıf içi öğretim etkinliklerinde etkin (katılımlı) dinleme tekniği olarak dönütü nasıl ve ne oranda kullanmaktadır?

\section{Alt Problemler}

1. Öğretmenlerin etkin dinleme teknikleri ile ilgili bilgileri ve uygulamaları nelerdir?

2. Öğretmenlerin yansıtma, duyguların anlaşıldığını gösterme ve soru sorma etkin dinleme tekniklerini sınıf içinde kullanma durumları ne orandadır?

\section{Yöntem}

\section{Çalışma Grubu}

Araştırma uygulaması, Bolu il merkezindeki ortaokullarda görev yapan 89 Türkçe öğretmeni arasından 10'u ile yapılmıştır. Bu öğretmenler, Bolu'da 6 farklı ortaokulda görev yapmaktadır. Öğretmenlerin belirlenmesinde amaçlı örnekleme yöntemi ve tabakalı örnekleme tekniği kullanılmıştır. Tabakalı amaçlı örnekleme yapılırken öğretmenlerin cinsiyeti, yaş aralığı ve çalıştıkları okulun il merkezine olan uzaklığı ile bulunduğu sosyoekonomik çevre dikkate alınmıştır. Okullar il merkezine uzaklığı ve sosyoekonomik düzeyine göre "düşük, orta ve yüksek" olarak sınıflandırılmış, daha sonra bu okullardan ulaşımı maliyet açısından kolay olan her düzeyden 2'şer tanesindeki gönüllü öğretmenlerle araştırma yürütülmüştür. Bolu il merkezindeki Türkçe öğretmenlerinin \%31'i bay, 35 kişi; \%69’u bayan, 54 kişidir. "24-30 yaş aralığı”nda 31 bayan, 16 bay; “30-40 yaş aralığı”nda 19 bayan, 15 bay ve "40 yaş üzeri aralığı"nda 4 bayan, 4 bay bulunmaktadır. Bunlar arasından "24-30 yaş aralığı”nda 3 bayan, 2 bay; “30-40 yaş aralı̆ıı”nda 2 bayan, 2 bay ve "40 yaş üzeri aralığı”nda ise 1 bay; toplamda 5 bayan ve 5 bay öğretmen ile çalışılabilmiştir. Farklı özelliklere sahip öğretmenlerin ve okulların belirlenmiş olması, toplanan verilerin çeşitliliğinin arttırılmasını sağlama amacını taşımaktadır.

\section{Veri Toplama Araçları}


Türkçe öğretmenlerinin etkin dinleme ve dönüt durumlarının incelenmesi için alan yazında kabul gören ve yukarıda açıklanan yansıtma, duyguların anlaşıldığını gösterme ve soru sorma teknikleri ve açıklanan alt özellikleri, üç alan uzmanının görüşleri de alınarak "Kontrol Listesi"ne dönüştürülmüştür.

Ayrıca, "Kontrol Listesi"ndeki etkin dinleme ve alt teknikleri üç alan uzmanın görüşü alınarak açık ve kapalı uçlu sorulardan oluşan "Etkin Dinleme Görüşme Formu"na dönüştürülmüştür. Daha sonra araştırmaya katılan öğretmenlerle yüz yüze görüşme yapılarak bu tekniklerin ne olduğu bilgisi ve bunları derslerinde kullanıp kullanmadıkları ile ilgili farkındalıkları anlaşıımaya çalışılmıştır.

\section{Verilerin Toplanması}

Veri toplama aşaması gözlem ve görüşme uygulamalarından oluşmuştur. Belirlenen ortaokullardaki sınıflarda öğretmenleri gözlemleme, daha sonra onlarla konuyla ilgili görüşme yapılabilmesi için Bolu î Milli Eğitim Müdürlüğü'nden resmi izin alınmıştır.

Veri toplama aşamasından önce araştırmanın güvenilirliğini sağlamak amacıyla ön uygulama yapılmıştır. Ön uygulama için belirlenen okulda aynı anda ve sınıfta iki araştırmacı gözlem yapmış, kayda geçirdikleri verilerin birbiriyle tutarlı olup olmadığı incelenmiştir. "Kontrol Listesi”ndeki etkin dinleme teknikleriyle ilgili iki araştırmacı arasındaki değerlendirme uyuşmazlıkları giderilmiş, genel olarak ön uygulamadan elde edilen verilerin \%90 oranında birbiriyle tutarlı olduğu görülmüştür.

Araştırmada ilk olarak üç hafta boyunca Türkçe derslerinde öğretmenlerin etkin dinleme tekniklerini kullanma durumları gözlemlenmiştir. Bunun için altı ortaokulda görev yapan 10 Türkçe öğretmeninin her biri farklı iki günde ve ikişer saat gözlemlenmiş, işledikleri derslerde kullandıkları etkin dinleme tekniklerini içeren, öğrencilerle olan sınıf içi diyalogları kayda geçirilmiştir. Öğretmenleri Türkçe derslerinde üç hafta gözlemledikten sonra etkin dinleme teknikleri ile ilgili bilgilerini ve kullanım farkındalıklarını belirlemek için de "Etkin Dinleme Görüşme Formu" kullanılarak onlarla yüz yüze görüşme gerçekleştirilmiştir. Öğretmenlerin etkin dinleme teknikleri ile ilgili görüşlerini aktarırken her görüşme sorusu için A1, A2 ..; B1, B2...; C1,C2 ... vd. gibi farklı kodlar kullanılımıştır.

\section{Sınırlılıklar}

Veri toplamada şunlara dikkat edilmiştir: Sınıf ortamında öğrencinin söylediğine öğretmenin karşılık verdiği her iletişim durumu, toplanan verilere dâhil edilmemiştir. Bunun için kullanılan ölçüt, öğrencinin söz alması ve öğretmenin de onu dikkate almasıdır. Diğer dönütler; örneğin öğrenci söz almadan konuşup öğretmenin tepkide bulunduğu durumlar değerlendirilmemiştir. Ayrıca öğrenciye bir şeyler okutulduğunda öğretmenin verdiği dönütler de değerlendirilmemiştir. Çünkü araştırmanın konusu, sadece karşılıkı konuşmada etkin dinleme ve dönüt ile sınırlandırılmıştır.

\section{Verilerin Analizi}

Sınıflarda yapılan gözlemler ve alınan kayıtların içerik analizi yapılmıştır. Gözlem esnasında kayda geçirilen dönütlerden bir kısmı, etkin dinleme tekniği olma özelliği taşımamaktadır. Örneğin 
bilgi aktarma, söylenenleri düzeltme, onaylama ve reddetme, öğrenciyi övme ve yerme gibi olumluolumsuz dönütler ile sözel olarak değer taşımayan, beden dili ögeleri olan jest ve mimikler. Bunlar etkin dinlemenin dışında, "diğer dönütler" başlığı altında değerlendirilmiştir.

Gözlem ve görüşme yoluyla toplanan verilerle baş etmek, bir arada kontrolünü kolaylaştırmak için yazılı kayıtlar, QSR NVivo 10. nitel veri analiz yazııımına aktarılmıştır. Bu verilerin içerik analizi yapılarak etkin dinlemenin üç tekniği ve üç tekniğin de alt kategorilerine fişlenmiştir. Bunların dışında kalanlar ise "diğer dönütler" başlığı altında değerlendirilmiştir. Bu işlemle betimsel veri analizi için "çerçeve oluşturma" ve "tematik çerçeveye göre verilerin işlenmesi" gerçekleştirilmiştir (Yıldırım ve Şimşek, 2006: 224). Araştırmanın amacına uygun olarak sınıf ortamında öğretmenlerin kullandığı dinleme teknikleri, yansıtma, duyguların anlaşıldığını gösterme ve soru sorma üç ana başlık altında sınıflandırılmış, Türkçe öğretmenlerinin ana ve alt teknikleri kullanım sıklıkları ve oranları sayısal verilere dönüştürülerek değerlendirilmiştir. Diğer dönütler ise genel bir başlık altında, içeriği sınıflandırılmadan kullanım sayısı ve oranı bakımından değerlendirilmiştir.

\section{Bulgular}

Öğretmenlerin Etkin Dinleme Teknikleri ile Ilgili Bilgileri ve Uygulama Durumlarına ilişskin Bulgular

Etkin Dinleme Görüşme Formu kullanılarak yapılan görüşmelerde öğretmenlere etkin dinleme hakkında neler bildikleri sorulmuştur. Bu sorunun amacı, öğretmenlerin etkin dinlemeyi ve tekniklerini ne kadar bildiklerini öğrenmektir.

Etkin dinlemenin ne olduğuna ilişkin soruya verilen cevaplar, öğretmenlerin etkin dinleme hakkındaki bilgilerinin oldukça yetersiz olduğunu göstermektedir. Çalışmaya katılan öğretmenlerin yarısı, etkin dinlemeyi tamamıyla yanlış açıklamışır. Dört öğretmenden ikisi, eksik olmakla birlikte etkin dinlemeye ait özellikleri şu şekilde ifade etmiştir:

A1 Etkin dinleme öğrencinin sürece dâhil edilmesidir bana göre. Hani pasif olarak öğretmenin anlattığı şeyleri ders boyunca dinlemesi değil de, sürece dâhil edilmesi olarak düşünüyorum. Daha çok öğrenci merkezli sistemlerde olur bu. Öğrenci bütün ders boyunca öğretmenin anlattıklarını dinler. Ama hiçbir şekilde anlayıp anlamadığını dile getirmez veya konu hakkında konuşmaz, kendi düşüncelerini söylemez. Yani pasif bir dinleyicidir, etkin dinleyici değildir. Etkin dinleme bana göre öğrencinin sürece dâhil edilmesi, konu üzerinde kendi görüşlerini ifade etmesidir.

A2. Etkin dinleme öğrenciye dinlediğini belli eden, ona geri dönütler veren dinleme şeklidir, diye biliyorum.

Öğretmenlerin yaptıkları bu tanımlar, etkin dinlemenin temel özelliklerinden birçoğunu içermemektedir. Bu veriler, öğretmenlerin etkin dinleme bilgisinin yeterli olmadığı şeklinde yorumlanabilir.

Görüşme kapsamında sorulan sorulardan birisi, öğretmenlerin kendilerini ne derece etkin bir dinleyici olarak gördükleridir. Bu soru, görüşmenin sonunda sorulmuştur. Bunun sebebi, öğretmenlerin sorular sayesinde etkin dinleme ile ilgili daha fazla bilgi sahibi olmalarını sağlamaktır. 
Öğretmenlerin tamamı, iyi ve etkin birer dinleyici olduğunu belirtmiştir. Öğrenciyi dinlemenin öneminin farkında olduklarını gösteren ifadeler kullanan öğretmenler, bunda sınıf içı bazı etkenlerin belirleyici olabildiğini vurgulamıştır. Öğretmenlerin sınıf içi ortam ile ilgili görüşleri şunlardır:

A3. Ben öğrencime söz vermişsem eğer, onu sonuna kadar dinlerim, sözünü kesmem bir kere; onu söyleyeyim. Ama dinleme sırasında, dediğim gibi, dikkatim dağılabiliyor ortama bağı olarak. Ortam çok sessizse güzel bir şekilde dinliyorum öğrencimi. Gerektiğinde işte görüşlerini geliştiriyorum, onun sözlerine bir şeyler katıyorum hani faydalı olması açııından sınıfa. Ama çok gürültülüyse ortam, dediğim gibi, çok da böyle iyi dinleyemiyorum öğrenciyi. $O$ anda başkasını susturmak zorunda kalıyorum, başkasıyla göz teması kurmak zorunda kalıyorum susması için, onu dinlemesi için. Ortamına göre değişiyor, öyle diyeyim.

Bir başkasına göre öğretmenin psikolojik durumu bu konuda oldukça belirleyicidir.

A4. ... çok da gerçekçi tavır değil. Olmaması da gerekir. Sonuçta öğretmen de insandır. Öğrenci de insandır. Yaşadığı sıkıntılar en azından beden diline yansır. Ne olabilir; mesela ben sinirliyim diye gidip sınıfı azarlamama gerek yok. Yine gülümserim, ama gülümsememdeki tat farklıdır. Ya da ne olabilir? Belki belli etmemeye çalışırım. Belli etmemeye çalışırken ne yaparım? Daha az konuşmayı tercih edebilirim. Ama bunları yaparken dinleme noktasında... Dinlediğimi düşünüyorum açıkçası. "Sizi dinlemiyorum!" Belki hani şunu yaptığım zamanlarım var. Çok çok yoğunsam ve sınıfa gerçekten adapte olamayacaksam serbest etkinlik, görevlendirme şeklinde, serbest etkinlik ya da yazı çalışması şeklinde sınıfı bırakıp ayrıca belki bire bir şeye düşebilirim. $\mathrm{O}$ anda mesela metin işlemiyorum ya da o an işlemem gereken bir şey varsa işlemiyorum. Çünkü ben de yoğunlaşamıyorsam eğer, anlatmama yoğunlaşamıyorsam dinlemeye de yoğunlaşamayacağım, demektir bu.

İnsan psikolojisinin iletişime etkisi burada bir örnek üzerinde görülebilmektedir. Başka bir

öğretmen, etkin dinleme konusunu öğrencinin psikolojisi üzerinden şu şekilde ele almaktadır:

A5. O korkuyu yendikten sonra öğrenci, ders boyunca konuşsa bile dinlerim ben onu. Bunu da hep söylüyorum zaten. Gereksiz konuşmayın, ama söz hakkı alın, kırk dakika boyunca konuşun. Yani ben mesela bugün çok önemli bir konu işleyeceğim. Ama öğrenci parmak kaldırıp da "Hocam, ben bir konu hakkında bir şey konuşmak istiyorum." dediği zaman kırk dakika boyunca bile dinleyebilirim. Çünkü o moda çok zor durumlarda gelmiştir ve her zaman o modu da yakalayamayabiliyor.

Bilindiği ve örneklerde görüldüğü üzere sınıf içi iletişimi, etkin dinlemenin gerçekleşmesini etkileyen değişkenler vardır. Bunların olumsuz olanları, aslında birer dinleme engelidir. Bu engeller konuşanla veya dinleyenle ilgili olabilmektedir (Özbay, 2005: 115-125). Dinlerken dönüt kullanma, daha önce de ifade edildiği gibi etkin dinlemenin temelidir. Konuşana etkin bir şekilde dinlenildiğini gösteren, dönüttür.

Öğretmenlere sınıf içi iletişimde öğrencileri ne kadar dinlediklerini ve dönütlerden ne kadar yararlandıklarını öğrenme amacı taşıyan bir soru sorulmuştur. Öğretmenler, genel olarak öğrencileri dinlediklerini ve dönütler verdiklerini belirtmişlerdir. Bunu doğrulamak için, araştırmanın ikinci problemi ile ilgili bu görüşmeden önce yapılan sınıf içi gözlem verileri aşağıda verilmiştir.

\section{Öğretmenlerin Etkin Dinleme Tekniklerini Sınıf İ̧̧inde Kullanma Durumlarına ilişskin Bulgular}

Gözleme dayalı olarak toplanan, öğretmenlerin yansıtma, duyguların anlaşıldığını gösterme ve soru sorma etkin dinleme tekniklerini sınıf içinde kullanım sıklıkları ve oranları Tablo 1'de verilmiştir:

Tablo 1. Etkin dinleme tekniklerinin kullanım sıklıkları ve yüzdeleri 


\begin{tabular}{lccc}
\hline \multicolumn{1}{c}{ Dönüt Türleri } & Kullanım Sayısı & $\begin{array}{c}\text { Grup İçi } \\
\text { Kullanım } \\
\text { Yüzdesi (\%) }\end{array}$ & $\begin{array}{c}\text { Grubun Genel } \\
\text { Toplama Oranı } \\
\text { (\%) }\end{array}$ \\
\cline { 1 - 3 } 1. Yansıtma & 140 & 75,67 & 15,20 \\
a. Aynen tekrar etme & 88 & 47,56 & 9,55 \\
b. Başka türlü ifade etme & 12 & 6,48 & 1,30 \\
c. Anahtar kelimeyi söyleme & 10 & 5,40 & 1,08 \\
ç. Özetleme & 13 & 7,02 & 1,41 \\
d. Yorumlama & 17 & 9,18 & 1,84 \\
2. Duyguların anlaşıldığını gösterme & 0 & 0,00 & 0,00 \\
3. Soru sorma & 45 & 24,32 & 4,88 \\
a. Açık uçlu soru sorma & 24 & 12,97 & 2,60 \\
b. Açıklatıcı soru sorma & 17 & 9,18 & 1,84 \\
c. Sondaj sorusu sorma & 4 & 2,16 & 0,43 \\
Toplam (etkin dinleme teknikleri) & 185 & 100,00 & 20,08 \\
Diğer dönütler & 736 & - & 79,91 \\
Genel toplam (bütün bildirimler) & 921 & - & 100,00 \\
\hline
\end{tabular}

Tablo 1'de görüldüğü üzere öğretmenlerin sınıf içi iletişimde kullandığı etkin dinleme tekniği olmayan diğer dönütlerin sayısı 736, etkin dinleme tekniklerinin sayısı 185'tir. Öğretmenlerin sınıfta kullandığı etkin dinleme dışındaki dönütler yaklaşık \%80 oranında iken etkin dinleme tekniklerini kullanma oranı \%20 civarındadır. Ders esnasında söz hakkı alarak konuşan öğrencilere verilen her dönütün etkin dinleme tekniği olduğu söylenemez. Kaldı ki bunun böyle olduğu yönünde alan yazında herhangi bir bilgi de yoktur. Buna rağmen öğretmenlerin sınıf içi iletişimde etkin dinleme ve dönüt tekniklerini kullanma oranlarının genel olarak yetersiz olduğu söylenebilir.

\section{Yansıtma Tekniğinin Kullanımına illişkin Bulgular}

Tablo 2'de öğretmenlerin yansıtma tekniğini diğer etkin dinleme tekniklerine göre kullanma oranı verilmiştir.

Tablo 2. Yansıtma tekniklerinin kullanım sıklıkları ve diğer tekniklere göre yüzdesi

\begin{tabular}{lccc}
\hline \multicolumn{1}{c}{ Etkin Dinleme Tekniği } & Kullanım Sayısı & $\begin{array}{c}\text { Teknik İçi } \\
\text { Kullanım } \\
\text { Yüzdesi (\%) }\end{array}$ & $\begin{array}{c}\text { Tekniğin Genel } \\
\text { Toplama Oranı } \\
(\%)\end{array}$ \\
\hline 1.a. Aynen tekrar etme & 88 & 62,85 & 47,56 \\
1.b. Başka türlü ifade etme & 12 & 8,57 & 6,48 \\
1.c. Anahtar kelimeyi söyleme & 10 & 7,14 & 5,40 \\
1.ç. Özetleme & 13 & 9,28 & 7,02 \\
1.d. Yorumlama & 17 & 12,14 & 9,18 \\
\end{tabular}




\begin{tabular}{lccc} 
Toplam (yansıtma teknikleri) & 140 & 100,00 & 75,67 \\
$\begin{array}{l}\text { Diğer etkin dinleme teknikleri } \\
\begin{array}{l}\text { Genel toplam (tüm etkin dinleme } \\
\text { teknikleri) }\end{array}\end{array}$ & 45 & - & 24,33 \\
\hline
\end{tabular}

Yapılan gözlemlerde yansıtma tekniği, öğretmenler tarafından 140 defa kullanılmıştır. Bu sayı, etkin dinleme teknikleri içinde \%75,67'lik bir oranı oluşturmaktadır. Bu durum, yansıtmanın öğretmenler tarafından sıklıkla kullanıldığını göstermektedir. Yansıtma teknikleri arasında öğretmenler özellikle öğrencilerin ifadelerini aynen tekrar etmeyi 88 defa, \%62,85 oranında kullanmaktadır. Bunun dışındaki yansıtma tekniklerinin kullanım oranlarının benzer olduğu söylenebilir.

Beş tekniğin bulunduğu yansıtmada, çoğunluğun aynen tekrar etmeden oluştuğu görülebilmektedir. Ayrıca aynen tekrar etmenin kullanım sıklığı, bütün etkin dinleme tekniklerinin hemen hemen yarısını oluşturmaktadır. Bu hâliyle bu teknik, en çok kullanılan dönüt türüdür. Nitekim öğretmenlerle yüz yüze yapılan görüşmede de teknikten çokça yararlandıklarını ifade etmişlerdir. Ancak öğretmenlerin birkaçı, bunun yerine başkasını kullanmanın daha yararlı olduğunu söylemiştir. Bir öğretmen aynen tekrar etmek yerine, söylediklerinden ne anladığını öğrenciye geri iletme yolunu seçtiğini ifade etmiştir. Bir başkası aynı şeyi "Bunu mu demek istedin?" sorusuyla birlikte yaptığını belirtmiştir. Bu soruyla öğrencinin söylemek istediğinin anlaşıldığı doğrulanmış olmaktadır. Aynen tekrar etme tekniğinin sınıfta kullanımına örnek olarak öğretmen-öğrenci arasında geçen şu diyaloglar örnek verilebilir:

B1. Öğrenci: Tutumlu olmak parasını yerinde harcamaktır.

Öğretmen: Tutumlu olmak parasını yerli yerinde harcamak, gerektiğinde harcamaktır.

B2. Öğrenci: Öğretmenim, parasını her şeye saçmayan.

Öğretmen: Parasını her şeye saçmayan.

B3. Öğrenci: Hayatın gerçekleri. [Başılık tavsiyesi]

Öğretmen: Hayatın gerçekleri.

B4. Öğrenci: Bazı tellaklar iyi keselemiyor.

Öğretmen: Bazı tellaklar iyi keseleyemiyor.

B5. Öğrenci: Öğretmenim, bizim evde hiç kural yok.

Öğretmen: Hiç kural yok.

B6. Öğrenci: Mecaz anlam.

Öğretmen: Mecaz anlam.

Bir öğretmen bu tekniğin bir yararını şu şekilde ifade etmiştir:

B7. "Aynen tekrar etme"den çokça yararlanıyorum. Bunu biraz da şey için de yapıyorum: Dinlememiş olan öğrencilere tekrar duyurmak için de yapıyorum sonunda."

Bu yolla öğretmen hem konuşan öğrenciye onu dinlediğini göstermiş hem de onu dinlemeyen öğrencilerin dinlemesini sağlamış oluyor. Aynen tekrar etme tekniğinin anlama gerçekleşmeden 
kullanılma ihtimali diğer yansıtma tekniklerine göre daha fazladır. Çünkü diğer yansıtma teknikleri için anlamlandırmanın tamamlanması ve anlamın başka bir dil yapısına dönüştürülmesi gerekir. Oysa aynen tekrar etmede konuşanın ifadelerini dinleyicinin dönüştürmesine gerek yoktur.

Başka türlü ifade etme tekniği, öğretmenler tarafından 12 kez kullanılmıştır. Bu sayı, yansıtma türü dönütlerin $\% 8,57$ 'si, etkin dinleme tekniklerinin ise $\% 6,48$ 'ini oluşturuyor. Görüldüğü üzere bu tekniğin kullanım miktarı, aynen tekrar etmeye göre oldukça düşüktür. Öğretmenlerden biri, bu tekniği nasıl kullandığını şu şekilde açıklamıştır:

C1. Ona anladığımı ifade eden, onun bana aktardığından benim ne anladığımı bir kez daha ifade ediyorum çoğu kez.

Bu açıklamada öğretmen, öğrencinin iletisini anladığını göstermektedir. Başka türlü ifade etme tekniğinin sınıfta uygulanışına örnek, şu diyaloglar verilebilir:

C2. Öğrenci: Öğretmenim, bir şeyin değerini bilmek. Yani S.'nin dediği gibi, öğretmenim, evden getirip de farklı bir şey yapacağına oradan buluyor. Oradakilerin değerini biliyor en azından yani.

Öğretmen: Yani atıl durumda olan eşyaları değerlendiriyor, işe yarar hâle getiriyor, diyorsun, değil mi? Tutumlu olmanın da bir parçası da budur.

C3. Öğrenci: Böyle ancak işte apartmanda görüşürlerse merhaba diyorlar, gidiyorlar.

Öğretmen: Evet. Giriş çıkışlarda karşılaşırlarsa, evet, merhabalaşıyorlar.

C4. Öğrenci: Öğretmenim, akşam namazından sonra gelirsek evde şenlik var.

Öğretmen: Akşam ezanından sonra eve girmek yasaktır.

Verilen örneklerde öğretmenin, öğrencinin söylediklerini, anlamını bozmadan başka sözcüklerle yansıttığı görülmektedir.

Anahtar kelimeyi söyleme tekniği, öğretmenler tarafından 10 kez kullanılmıştır. Bu sayı, yansıtma tekniklerinin \%7,14'üne karşılık gelmektedir. Anahtar kelimeyi söyleme, etkin dinleme tekniği olan dönütlerin \%5,4'ünü oluşturmaktadır. Bu tekniğin sınıfta uygulanışına örnek olarak şu diyaloglar verilebilir:

D1. Öğrenci: Bence, öğretmenim, hani insanlara rehber olacak kişi.

Öğretmen: Peki. Mevlana rehber.

D2. Öğrenci: Öğretmenim, küçükken ben çamurdan kum torbaları yapıyordum.

Öğretmen: Çamurdan kum torbaları.

Burada öğretmenler, verdikleri dönütlerde anahtar kelimeyi söyleyerek, ifade edilenlerdeki ana konuyu kaçırmadıklarını göstermektedirler.

Özetleme tekniği, öğretmenler tarafından 13 kez kullanılmıştır. Bu sayı, yansıtma tekniklerinin $\% 9,28$ 'ine, etkin dinleme tekniği sayılan dönütlerin \%7,02'sine tekabül ediyor. Araştırmada gözlemlenen öğretmenlerden beşi, özetlemeyi daha ziyade sınıftaki birkaç öğrencinin söylediğini toparlama şeklinde yaptıklarını ifade etmiştir. Bu tür özetleme sınıfa yönelik ve genel olduğu için etkin dinleme tekniklerinden birine dâhil değildir. íki öğretmen ise özetlemeyi, öğrencilerin ifade etmek 
isteyip de edemediklerini anladıktan sonra derleyip toparlama ve daha anlaşılır kılma şeklinde kullandığını belirtmiştir. Bu öğretmenlerden birisi, bu durumu şöyle açıklamıştır:

E1. Evet. Çünkü öğrenciler aslında bazı şeyleri biliyorlar, ama cümlelere dökmekte sorun yaşıyorlar. Yani ben o anki yüz ifadesinden söylemek istediğini anlıyorum. Bazen çok dağınık cümleler kuruyorlar. Sınıf daha iyi anlasın diye, bir de o kendini daha iyi hissetsin diye böyle son bir toparlama olarak ben de cümleyi söylüyorum. Ama onun cümlesinin bitmesini bekliyorum.

Özetleme tekniğinin sınıfta uygulanışına örnek, şu diyaloglar verilebilir:

E2. Öğrenci: Öğretmenim, oyun bir organ gibidir. Bir çocuğun organı gibidir. Yani onu yapmazsak, yani o işlemi yerine getirmezsek psikolojikman etkilenir; asosyal olur, sosyalleşemez.

Öğretmen: Yani oyunun insanın sosyalleşmesi açısından önemi çok büyüktür, diyorsun. Değil mi?

E3. Öğrenci: Öğretmenim, burada "Fakat çarşıya gidebiliriz." bir cümle oluyor. "Önce şunu bitirelim." bir cümle oluyor. Bu cümleleri bağlıyor.

Öğretmen: Aferin, güzel. Görevi cümleleri birbirine bağlamak.

E4. Öğrenci A: Bir de mesela 5'ten 6'ya kadar oynayabiliriz. 6 buçuğa kadar... Nasıl anlatayım?

Öğrenci B: Bir buçuk saati falan geçmeyecek.

Öğrenci A: Evet. Şu saatten şu saate oynayabilirsin. Ama onu aşmayacaksın.

Öğretmen: Oyun saatleriniz var. O saati aşmak yasak.

Örneklerde görüldüğü üzere öğretmenler, öğrencilerin söylediklerini özetleyerek dinlediklerini göstermektedirler.

Yorumlama tekniği, öğretmenler tarafından 17 kez kullanılmıştır. Yansıtma tekniklerinin \%12,14'ünü oluşturan bu oran, etkin dinleme tekniklerinin 9,18'ine karşlık gelmektedir. Bu tekniği nasıl kullandığını bir öğretmen şu şekilde açıklamıştır:

F1. Onun fikirlerinin üzerine. Mesela orada konu üzerine görüşünü belirttikten sonra ben de ona ilave olarak bir şeyler söylüyorum.

Yorumlama tekniğinin sınıfta uygulanışına örnek, şu diyaloglar verilebilir:

F2. Öğrenci: Z. baktı. Okurken bize baktı. Sonra bir yeri şaşırdı. Sonra bir de Z. mesela okurken şöyle yaptı. "Sen bizimle alay mı ediyorsun?" Kaşlar çatık, sanki kendisi yaşamış gibi yaptı.

Öğretmen: Evet, bu güzel bir özellik.

F3. Öğrenci: Şimdi oynamıyorum da küçükken oynadığımı zaman taşlardan telefonumuz olurdu.

Öğretmen: Bak! Taşlardan telefon. Sokaktaki herhangi bir şeyi kullandığı araç gerece ya da eşyalara benzeterek bir ev ortamı gibi oluşturuyor.

F4. Öğretmen: Yaptın mı hiç bez bebek?

Öğrenci: Evet.

Öğretmen: Sen bayağı modern bir oyun çıkardın ortaya. 
F5. Öğrenci: Kızarım, doğrusunu söylerim.

Öğretmen: Illk önce kızarsın, sonra doğrusunu söylersin. Farklı bir yaklaşım.

F6. Öğrenci: Hocam, bizim köyde bir tane köpeğimiz vardı. Çok iyi... Ben çok seviyordum. Dedem yatıyordu. Dedemin yanına yatıyordu. Sarıııordu böyle.

Öğretmen: Gerçekten köpekler çok sadıklar.

Bu örneklerde öğretmenlerin, öğrencinin söylediklerine yeni bir bakış açısı getirdikleri, ifade edilenleri yorumladıkları, dinlediklerini bu şekilde gösterdikleri görülmektedir.

\section{Duyguların Anlaşıldığını Gösterme Tekniğine Illişkin Bulgular}

Duyguların anlaşıldığını gösterme tekniği, öğretmenler tarafından hiç kullanılmamıştır. Öğretmenlerle yüz yüze yapılan görüşme verilerine bakılırsa çoğu bu konuda olumlu cevap vererek bu tekniği kullandığını söylemiştir. Öğretmenlerden biri duyguların anlaşıldığını göstermenin şartlara bağlı olarak kullanılması gerektiğini ifade etmiştir. Ona göre genel özellik taşımayan birtakım duyguların açığa çıkarııması doğru değildir.

G1. Ya, şöyle söyleyeyim. Konunun çeşidine göre değişir. Mesela bazen oluyor ki ölümden bahsediyor. Bir anne ölümü ardından söylenen bir şey. Mesela ben o an orada öğrencinin cümle kurarken hissettiklerini gör..., mutlaka bunun altında bir şey olduğunu düşünüyorum. Ya bir annesini kaybetmiştir. $O$ an duygularını çok fazla deşifre etmiyorum. Çok fazla yarasını kurcalamıyorum. Ama çok genel bir konuysa tabii ki onun o duygularından daha da yararlanmaya çalışıyorum.

Öğrencinin ifadelerinden çıkarılan duyguların açığa vurulmasının çoğu zaman doğru olmayacağını düşünen diğer öğretmen, bu düşüncesini şu şekilde ifade etmiştir:

G2. Yok. Onu, onu çok yapmıyorum ya. Yani onu fark etmek zor değil. Zaten özellikle ses tonundan, vurgusundan zaten rahat olarak duygu ifadesi çıkıyor ortaya, ama ben açıkçası onu çok da onaylamıyorum. Neden onaylamıyorum? Çünkü bu "Sen böyle düşündün. Böyle hissettin." ifade etmek için çocuğun rahat olması lazım. Rahat olması ancak ikili ilişkilerde mümkündür. Sınıf ortamında otuz kişinin olduğu bir yerde "Sen üzüldün." demek de incitebiliyor bazen. Ya da işte "Sen buna kızdın. Sen kızdın ve ben bunu fark ettim." demek, bu da bazen incitebiliyor. Zaman zaman olumlu tepkilerde bunu yapabiliyoruz, ama genel anlamda ben çok da olumlu bulmuyorum açıkçası.

Bu tekniğin hiç kullanılmamış olması, yalnızca sınıf ortamında duyguların açığa vurulmasının doğru olmadığı düşüncesine bağlanamaz. Çünkü daha önce ifade edildiği gibi öğretmenlerin yarısından fazlası, bu tekniği kullandığını söylemiştir. Kaldı ki olumlu da olsa hiçbir duygunun açığa çıkarılmaması gerektiğine dair bilimsel bir veri de yoktur.

\section{Soru Sorma Tekniğine ilişskin Bulgular}

Aşağıdaki tabloda soru sorma tekniklerinin kendi içerisindeki dağılımı ile bütün etkin dinleme tekniklerine göre kullanım oranı yer almaktadır.

Tablo 3. Soru sorma tekniklerinin kullanım sıklıkları ve diğer tekniklere göre yüzdesi

\begin{tabular}{lccc}
\hline Etkin Dinleme Tekniği & Kullanım Sayısı & $\begin{array}{c}\text { Teknik İçi } \\
\text { Kullanım } \\
\text { Yüzdesi (\%) }\end{array}$ & $\begin{array}{c}\text { Tekniğin Genel } \\
\text { Toplama Oranı } \\
(\%)\end{array}$ \\
\hline 3.a. Açık uçlu soru sorma & 24 & 53,33 & 12,97
\end{tabular}




\begin{tabular}{lccc} 
3.b. Açıklatıcı soru sorma & 17 & 37,77 & 9,18 \\
$\begin{array}{l}\text { 3.c. Sondaj sorusu sorma } \\
\text { Toplam (soru sorma teknikleri) }\end{array}$ & 45 & 8,88 & 2,16 \\
$\begin{array}{l}\text { Diğer dönüt teknikleri } \\
\begin{array}{l}\text { Genel toplam (bütün etkin dinleme } \\
\text { teknikleri) }\end{array}\end{array}$ & 140 & 100,00 & 24,32 \\
\hline
\end{tabular}

Soru sorma tekniği, öğretmenler tarafından 45 defa kullanılmıştır. Bu sayı etkin dinleme tekniklerinin \%24,32'sini, bütün dönütlerin \%4,88'ini oluşturmaktadır. Bu durum, soru sormanın, 140 kere yararlanılmış olan yansıtmanın üçte biri kadar kullanıldığını ortaya koymaktadır. Sınıf ortamında öğretmenlerin etkin dinleme tekniklerinden en çok yansıtma ve soru sormayı kullandıkları söylenebilir.

Birçok durumda, soru sormak için söylenilenleri anlamış olmak gerektiği bilinmektedir. Bu yüzden soru sorma tekniği, etkin dinleme sürecinde anlamanın gerçekleştiğini gösterme konusunda etkilidir. Ayrıca bu teknik, iletişim sürecinin akıcılığını sağlamada da önemli rol oynar. Soru yoluyla konu genişletilmiş, konuşma uzatılmış, merak duygusu açığa çıkarılmış ve konuşan kişi cesaretlendirilmiş olur.

Açık uçlu soru sorma tekniği, öğretmenler tarafından 24 defa kullanılmıştır. Bu kullanımlar, soru sormaya dâhil olan tekniklerin \%53,33'ünü, etkin dinleme tekniği olarak kullanılan tüm dönütlerin \%12,97'sini oluşturmaktadır. Bu tekniğin sınıfta uygulanışına şu diyaloglar örnek verilebilir:

H1. Öğrenci: Ne yapmallyız? [Kendisine sorulduğunu düşündüğü soruyu tekrar etti.] Öğretmen: Hayır. Ne yapmalıyız derken... Biz zaten konuştuk ne yapmamız gerektiğini de. Sen bu konudaki görüşlerini tekrar dile getirmek ister misin? Neler düşünüyorsun bu konuda bir B. olarak? B. burada bir birey, bir vatandaş oluyor, değil mi?

H2. Öğrenci: Arkadaşıma gıcık olur, daha sesli konuşurdum. Öğretmen: Bağııııdım duysun diye. Tekrar yanlış anlıyor?

H3. Öğrenci: Şimdi, maç izliyorduk. Beşiktaş'ın Avrupa Ligi'nde maçı, hocam. Adamlar o kadar gelişmiş ki, hocam, taç kullanırken havluyla siliyorlar topu; yerler ıslaktı. Bizim oyuncularımızda da öyle bir şey olmadığı için adamlar, formaları, topu üstünde temizleyip öyle taç kullanıyorlardı. $O$ oldu.

Öğretmen: Oradan ne çıkardın?

H4. Öğrenci: Öğretmenim, ama orada insanların o anın acısını unutmaması için ya da bunu hatırlamaları için etkinlikler yapılabilir.

Öğretmen: Nasıl etkinlikler mesela?

Öğretmenlerin açık uçlu soru olarak verdikleri dönütler, öğrencileri konuşmaya teşvik edici özelliklere sahiptir. Nitekim açık uçlu soruların önemli özelliklerinden birisi de budur (Hoppe, 2006: 
16).

Açıklatıcı soru sorma tekniği, öğretmenler tarafından 17 defa kullanılmıştır. Bu sayı, kullanılan soru sorma tekniklerinin $\% 37,77$ 'sine, etkin dinleme tekniklerinin ise $\% 9,18$ 'ine karşılık gelmektedir. Açıklatıcı soru sormanın sınıfta uygulanışına şu diyaloglar örnek verilebilir:

I1. Öğrenci: Erik ağaçlarının yok edilmesinden.

Öğretmen: Erik ağaçlarının?

12. Öğrenci: Oyuncakların ... ve çocuğun askere gitmiş bir babası olmalıydı. Pamuktan çocuğun yatağı olmalıydı. Öğretmenim, bir de kartlar oluyor ya, alışveriş kartları falan; benim babamın eski kartları var; onlarla oynuyorduk.

Öğretmen: Hee, peki. Kredi kartları mı?

13. Öğrenci: Hocam, mısırların dışındaki saç gibi küçük küçük şeyler oluyor kabuğunun dışında. Onlardan çocuklara saç yapardık.

Öğretmen: Mısırın püskülü, mü diyorsunuz?

14. Öğrenci: Evimi seviyorum, ama bazı sevmediğim kısımları da var. Öğretmenim, her yerde kamera var.

Öğretmen: Evde?

Öğretmenlerin bu örneklerde daha iyi anlama ve konuyu özetleme gayreti içerisinde oldukları söylenebilir. Bunu açıklatıcı soru sorma yoluyla gerçekleştirmeye çalışmaktadırlar.

Sondaj sorusu sorma tekniği, öğretmenler tarafından 4 defa kullanılmıştır. En az kullanılan teknikler sıralamasında, hiç kullanılmamış olan "duyguların anlaşıldığını gösterme"den sonra gelen sondaj sorusu sorma, soru sorma tekniği olan dönütlerin $\% 8,88^{\prime} i n i$, etkin dinleme tekniği olanların ise \%2,16'sını oluşturmaktadır. Bu tekniğin sınıfta uygulanışına şu diyaloglar örnek verilebilir:

i1. Öğrenci: Bir dakika. Aklıma gelecek. Haa, öğretmenim, biz tutumlu insanlara kısaca cimri diyoruz.

Öğretmen: Cimrilikle tutumlu olmak arasındaki fark yok mu?

i2. Öğrenci: Şiir kıta kıta..

Öğretmen: Kıtalar hâlinde yazılır. Peki eğer bir şiir kıta hâlinde yazılmazsa, yani dörtlük değil de beşlikten oluşursa ben ona şiir demez miyim?

Daha önce de ifade edildiği gibi sondaj soruları, muhatabın bir düşünceye ulaşmasını bir şey önermeden veya savunmadan sağlamak amacıyla sorulur (Hoppe, 2006: 16). Verilen örneklerde de bunun gerçekleştirildiği görülmektedir. Söz gelimi son örnekte öğrenciye doğrudan "Beşlikten oluşursa da o şiirdir." demek yerine yol gösterici bir soru sorularak doğruya ulaşması sağlanmaktadır.

Soru Sorma Tekniğinde Kullanılan Soruların Düzeyine ilişkin Bulgular

Öğretmenlerin sorduğu soruların Güncelleştirilmiş Bloom Taksonomisi'nde (Anderson vd., 2014: 375-376) yer alan bilişsel beceri basamaklarına dağılımını da önemlidir. Çünkü öğretmenler sordukları sorularla sadece iletişimin etkililiğini ve sağlıklı bir şekilde devam etmesini sağlamanın 
yanında öğrencilerin bilişsel becerilerinin gelişimine de katkı sağlarlar. Aşağıdaki tabloda soru sorma tekniklerinin hangi bilişsel beceri basamağında yer alan sorular sorularak kullanıldığı görülmektedir. Tablo 4. Öğretmenlerin sordukları soruların bilişsel beceri basamaklarına dağılımı

\begin{tabular}{|c|c|c|c|c|c|c|c|c|c|c|c|c|}
\hline \multirow{3}{*}{$\begin{array}{c}\text { Soru Sorma } \\
\text { Tekniği }\end{array}$} & \multicolumn{12}{|c|}{ Bilişsel Beceri Basamakları } \\
\hline & \multicolumn{2}{|c|}{ Hatırlama } & \multicolumn{2}{|c|}{ Anlama } & \multicolumn{2}{|c|}{ Uygulama } & \multicolumn{2}{|c|}{ Çözümleme } & \multicolumn{2}{|c|}{$\begin{array}{l}\text { Değerlen- } \\
\text { dirme }\end{array}$} & \multicolumn{2}{|c|}{ Yaratma } \\
\hline & $f$ & $\%$ & $f$ & $\%$ & $f$ & $\%$ & $f$ & $\%$ & $f$ & $\%$ & $f$ & $\%$ \\
\hline $\begin{array}{l}\text { Açık uçlu soru } \\
\text { sorma }\end{array}$ & - & - & 19 & 42,22 & 2 & 4,44 & 3 & 6,66 & - & - & - & - \\
\hline $\begin{array}{l}\text { Açıklatıcı soru } \\
\text { sorma }\end{array}$ & 13 & 28,88 & 4 & 8,88 & - & - & - & - & - & - & - & - \\
\hline $\begin{array}{l}\text { Sondaj sorusu } \\
\text { sorma }\end{array}$ & - & - & 1 & 2,22 & 1 & 2,22 & 2 & 4,44 & - & - & - & - \\
\hline Toplam & 13 & 28,88 & 24 & 53,33 & 3 & 6,66 & 5 & 11,11 & - & - & - & - \\
\hline
\end{tabular}

Tablo 4 incelendiğinde öğretmenlerin sordukları soruların alt düzey bilişsel beceri basamaklarından "hatırlama" ve "anlama"da yoğunlaştığı görülmektedir. Hatırlama basamağında 13, anlama basamağında ise 24 soru vardır. Uygulama basamağında yalnızca 3 soru, çözümlemede de 5 soru vardır. Anlama basamağında yer alan sorular, bütün soruların \%53,33'ini oluşturmaktadır. Soru sorma tekniğinde hatırlama düzeyine $\% 28,88$, çözümlemeye $\% 11,11$ ve uygulamaya $\% 6,66$ pay düşmektedir. Üst düzey bilişsel beceri basamağı olan çözümlemede yer alan 5 sorunun 3'ü açık uçlu, ikisi sondaj sorusudur. Çözümleme basamağında hiç açıklatıcı soru yoktur. Uygulama basamağında yer alan 3 soru da aynı şekilde açık uçlu soru ve sondaj sorusudur.

Öğretmenlerin etkin dinleme tekniği olarak sordukları soruların alt düzey bilişsel beceri basamaklarında yoğunlaştığı, üst düzey olan 5 sorunun ise açık uçlu soru sorma ve sondaj sorusu sorma tekniklerinde toplandığı görülmektedir. Ayrıca hatırlama basamağında bulunan soruların hepsinin açıklatıcı soru olması, diğer soru türlerinin öğretmenlerce kullanılmamış olması, öğretmenlerin dinlemede konunun kavranıp kavranmadığını ölçmede özetleme tekniğini kullanma eğiliminde olduklarını göstermektedir. Oysa Türkçe derslerinde kullanılan etkin dinleme tekniklerinden soru sormanın üst düzey bilişsel becerileri de destekler şekilde gerçekleştirilmesi öğrenciler için yararlı olurdu.

\section{Tartışma ve Sonuç}

Sınıflarda yapılan gözlemler sonunda öğretmenlerin etkin dinleme ve dönüt tekniklerinden en çok yansıtma tekniğini kullandıkları belirlenmiştir. Bütün etkin dinleme teknikleri içinde yansıtma tekniği \%75,67'lik bir orana sahiptir. Bu durum, yansıtmanın öğretmenler tarafından sıklıkla 
kullanıldığını göstermektedir. Ayrıca öğretmenler, yansıtma teknikleri arasında özellikle öğrencilerin ifadelerini aynen tekrar etme tekniğini \%62,85 oranında kullanmaktadır.

Öğretmeler yansıtma tekniğinden sonra ikinci sırada soru sorma tekniğini kullandıkları gözlemlenmiştir. Etkin dinleme teknikleri arasında soru sorma \%24,32'yi oluşturmaktadır. Öğretmenlerin soru sorma tekniğinde de en çok açık uçlu soruları kullanmayı tercih ettikleri, soru sorma teknikleri arasında açık uçlu soruların oranının yaklaşık \%53 olduğu belirlenmiştir.

Öğretmenlerle yüz yüze yapılan görüşmelerde çoğu, duyguların anlaşıldığını gösterme tekniğini kullandıklarını söylemişlerdir. Oysa sınıfta yapılan gözlemlerde öğretmenler bu tekniği hiç kullanmamıştır. Öğretmenlerden biri duyguların anlaşıldığını göstermenin şartlara bağlı olarak kullanılması gerektiğini ifade etmiş, bunu kullanırken sınıf ortamının bozulması ile ilgili çekinceleri olduğunu belirtmiştir.

Öğretmenlerle yapılan görüşmelerde aslında etkin dinleme ve dönüt teknikleri hakkında yeteri kadar bilgi sahibi olmadıkları belirlenmiştir. Öğretmenlerin etkin dinleme tekniği olarak sordukları sorular incelendiğinde durum daha iyi anlaşılmaktadır. Çünkü sınıf içi gözlemlerde öğretmenlerin sordukları soruların alt düzey bilişsel beceri basamaklarında yoğunlaştığı, sordukları soruların genellikle hatırlama ve anlama düzeyinde açıklatıcı sorular olduğu belirlenmiştir. Üst düzey bilişsel becerileri geliştiren soruların çözümleme düzeyinde açık uçlu ve sondaj sorusu olduğu, değerlendirme ve yaratma düzeylerinde hiç soru soramadıkları belirlenmiştir. Oysa Türkçe derslerinde kullanılan etkin dinleme tekniklerinden soru sormanın üst düzey bilişsel becerileri de desteklemesi öğrenciler için yararlı olurdu.

Etkin dinleme konusunda daha önce yapılan araştırmalardan hiçbiri, bu araştırmada olduğu gibi "etkin dinleme" becerisinin öğretmenler tarafından kullanılmasıyla ilgili gözleme dayalı değildir. Sosyal beceri olarak da etkin dinlemenin öğrenciye kazandırılması, aile ve yakın çevre kadar, belki de daha fazla öğretmenlerin iyi bir model ve öğretici olmasına bağlıdır. Etkin dinlemenin sınıf ortamında uygulanabilmesi, bu konuda diğer insanlara örnek olunabilmesi için de öncelikle konu hakkında öğretmenlerin bilgi sahibi olması gerekir. Çünkü bu beceriyi diğer iletişim becerilerinden ayıran bazı özellikler vardır. Bu beceri, insanlar arasındaki etkili iletişimi, anlaşmayı ve iyi ilişkileri geliştirmektedir (Nichols, 1995: 249). Ayrıca hayat boyunca her alanda kullanılabilmektedir ve sözlü iletişimin temeli olarak kabul edilebilecek özelliklere sahiptir (Yalçın, 2006: 132). Bu sebeple öğretmenlerin etkin dinleme ve dönüt teknikleri ile ilgili donanımlı ve bunu kullanıyor olması gerekir (İzin, 2006: 237). Ancak araştırma kapsamında görüşülen öğretmenlerin çoğunun, bu becerinin ne olduğunu bilmediği, bu beceriden haberdar olanların ise eksik bilgiye sahip oldukları için bununla ilgili dönüt tekniklerini yeterince veya hiç kullanmadıkları görülmüştür.

Öğretmenler, etkin dinleme hakkında çok az bilgiye sahip olmalarına rağmen bu beceriye ait teknikleri kullanmaktadırlar. Bunun sebeplerinden biri, soru sorma gibi bazılarının yaygın, herkesçe 
bilinen teknikler olmasıdır. Ayrıca bu durum, söz konusu tekniklerin hangi dinleme yöntemine ait olduğu bilinmeden kullanılıyor olması ile de açıklanabilir. Öğretmenler, bu teknikleri zaman içinde sınıf içi etkili iletişimin bir gereği olarak keşfetmiş ve uyguluyor da olabilirler. Hatta bu durum, öğrencinin anlaşııma arzusunu fark edip bu yönde davranış geliştirmenin bir sonucu olarak da ortaya çıkmış olabilir. Çünkü anlaşılma arzusu her insanda vardır ve duygudaşlık yoluyla diğer insanların bu özelliğinin farkına varılabilir.

Etkin dinleme tekniklerinden "duyguların anlaşıldığını gösterme"nin hiç kullanılmaması oldukça dikkat çekici olumsuz bir durum olarak değerlendirilebilir. Ancak bu olumsuzluğu bir miktar azaltabilecek olan etken, yapılan görüşmelerde birkaç öğretmen tarafından vurgulanmıştır. Bu öğretmenlerin ifadelerine göre öğrencinin duygularının sınıf ortamında açığa çıkarılması doğru değildir. Bu savın ortaya konulmasında çoğunlukla olumsuz örnekler üzerinden gidilmesi, bu savı zayıflatmışır. Çünkü bir öğrenci, sınıf ortamında hayvan sevgisi gibi olumlu ve ortak duyguları gösteren ifadeler de kullanabilir. Bu durumda da duyguların açığa çıkarılması sakıncalı mıdır? Ayrıca bu teknik kullanılmadan öğrencilerin duygudaşlık kurma becerileri nasıl geliştirilebilir? Bu sorular teknikle ilgili öğretmenlerin aslında bilmesi gereken önemli özelliklerdir. 


\section{Kaynakça}

Andersen, J. (2008). Developing Active Listening Skills. IDEA Fitness Journal, 85-87.

Anderson, L. W.; Krathwohl, D. R.; Airasian, P. W.; Cruikshank, K. A.; Mayer, R. E.; Pintrich, P. R.; Raths, J. ve Wittrock, M. C. (2014). Öğrenme, Öğretim ve Değerlendirme ile ilgili Bir Sınıflama (çev. D. A. Özçelik). Ankara: Pegem Akademi Yayınları.

Antai-Otong, D. (1999). Active Listening at Work. American Journal of Nursing, 2(99), 24L-24P.

Birden, N. (2001). Etkili Dinleme Sürecinde Öğretmen ve Yönetici Algılamalarının Karşılaştırılması. Yayımlanmamış Yüksek Lisans Tezi, Kocaeli: Kocaeli Üniversitesi Sosyal Bilimler Enstitüsü.

Bodie, G. D. (2011). The Active-Empathic Listening Scale (AELS): Conceptualization and Evidence of Validity within the Interpersonal Domain, Communication Quarterly, 3(59), 277-295.

Cheon, J. ve Grant, M. (2009). Web-Based Assessment Tool for Communication and Active Listening Skill Development. Tech Trends, 6(53), 24-34.

Cihangir Çankaya, Z. (2011). Kişilerarası Iletişimde Dinleme Becerisi (2. Baskı). Ankara: Nobel Yayınları.

Comer, L. B. ve Drollinger, T. (1999). Active Empathic Listening and Selling Success, A Conceptual Framework. Journal of Personal Selling \& Sales Management, XIX-1, 15-29.

Cüceloğlu, D. (2013). Yeniden Insan Insana (47. baskı). İstanbul: Remzi Kitabevi.

Çiftçi, Ö. (2007). Aktif Dinleme. Millî Eğitim Dergisi, 176(36), 231-242.

DeVito, J. A. (1995). The Interpersonal Communication Book. New York: Haper Collins College Publishers.

Doğan, Y. (2011). Dinleme Eğitimi. Ankara: Pegem Akademi Yayınları.

Gordon, T. (2004). Etkili Öğretmenlik Eğitimi (17. Baskı, Çev. E. Aksay). İstanbul: Sistem Yayıncılık.

Gordon, T. (2013). Etkili Öğretmenlik Eğitimi (5. baskı, çev. S. Karakale). İstanbul: Profil Yayıncılık.

Hanna, T. W. (2011). Assessing the Dimensionality of Active Listening in the Workplace. Yayımlanmamış Yüksek Lisans Tezi, San Jose: San Jose State University The Department of Psychology.

Hoppe, M. (2006). Active Listening Improve Your Ability to Listen and Lead. NC USA, Greensboro.

Hutchby, I. (2005). Active Listening: Formulations and the Elicitation of Feelings-Talk in Child Counselling, Research on Language \& Social Interaction, 38:3, 303-329.

İzin, N. (2006). Dil Becerilerinin Gelişiminde Öz Güven. Yayımlanmamış Yüksek Lisans Tezi, Ankara: Gazi Üniversitesi Eğitim Bilimleri Enstitüsü.

Karaköse, R. (2005). Ergenlerle Etkili iletişim. Ankara: Nobel Yayınları.

Lawrence, S. G. (1997). A Principal's Active Listening Skills and Teachers' Perceptions of the Principal's Leader Behaviors. Yayımlanmamış Doktora Tezi, MI: The University of Southern Mississippi.

MacKay, I. (1997). Dinleme Becerisi (Çev. B. Aksu ve O. Cankoçak). Ankara: Illk Kaynak Yayınları.

Matheson, S., Moon, M. ve Winiecki, A. (2000). Improving Student Ability to Follow Directions through the Use of Listening Skills Instruction. Yayımlanmamış Yüksek Lisans Tezi, Illinois: Saint Xavier University.

MEB (Komisyon) (2006). Ilköğretim Türkçe Dersi (6, 7, 8. Sınıflar) Öğretim Programı. Ankara: Millî Eğitim Bakanlığı Yayınları.

MEB (Komisyon) (2009). Türkçe Dersi Öğretim Programı ve Kılavuzu (1-5. Sınıflar). Ankara: Millî Eğitim Bakanlı̆ı̆ Yayınları. 
Mishima, N.; Kubota, S. ve Nagata, S. (2000). The Development of a Questionnaire to Assess the Attitude of Active Listening. Journal of Occupational Health, 42, 111-118.

Nichols, M. P. (1995). The Lost Art of Listening. New York: The Guilford Press.

Orlov, A. B. (1992). Carl Rogers and Contemporary Humanism. Journal of Russian and East European Psychology, $30,36-41$.

Özbay, M. (2005). Dinleme Eğitimi. Ankara: Akçağ Yayınları.

Rogers, C. R. (1955). Active Listening. Chicago, US: University of Chicago Industrial Relations Center.

Salem, R. (2003). Empathic Listening. (http://www.beyondintractability.org/essay/emphatic_listening/, 10.06.2014 tarihinde erişildi.)

Weger, H.; Castle, G. R. ve Emmett, M. C. (2010). Active Listening in Peer Interviews: The Influence of Message Paraphrasing on Perceptions of Listening Skill, International Journal of Listening, 24:1, 34-49.

Yalçın, A. (2006). Türkçe Öğretim Yöntemleri, Yeni Yaklaşımlar (2. baskı). Ankara: Akçağ Yayınları.

Yıldııım, A. ve Şimşek, H. (2006). Sosyal Bilimlerde Nitel Araştırma Yöntemleri (6. baskı). Ankara: Seçkin Yayıncılık. 